\title{
Forecast of climate-induced change in macrozoobenthos in the southern North Sea in spring
}

\author{
Joachim W. Dippner ${ }^{1, *}$, Ingrid Kröncke ${ }^{2}$ \\ ${ }^{1}$ Baltic Sea Research Institute Warnemünde, Seestr. 15, 18119 Rostock, Germany \\ ${ }^{2}$ Senckenberg Institute, Department for Marine Research, Schleusenstr. 39a, 26382 Wilhelmshaven, Germany
}

\begin{abstract}
A multivariate regression model using observed climate data is used to forecast the climate-induced changes in macrozoobenthos in spring. This is demonstrated by a forecast over $6 \mathrm{yr}$ of biomass, abundance and species number of macrozoobenthos communities in the southern North Sea. The partial linearity between climate and benthic variables, as well as the existence of a phase lag between climate variability during winter time and the response in macrozoobenthos in spring, makes the climate-induced variability in macrozoobenthos predictable. The results indicate that a major part of interannual and interdecadal variability of marine ecosystem, here demonstrated for macrozoobenthos, can be attributed to the physical forcing of winter climate.
\end{abstract}

KEY WORDS: Climate variability $\cdot$ Macrozoobenthos $\cdot$ Forecast $\cdot$ North Sea $\cdot$ Multivariate statistics

Many marine ecosystems around the world are currently undergoing dramatic changes in species composition due to the influence of human activity or due to climate events, resulting in a reduction in species diversity (Russell 1973, Avaria \& Munoz 1989, Carrasco \& Santander 1989). Changes in species composition, species richness, and/or functional diversity affect the sustainability of biological resources. Direct and indirect anthropogenic causes, such as overfishing, industrial and urban growth, pollution and eutrophication, losses of habitats, and changes in coastal morphology, suggest an ecosystem degradation (Goldberg 1994). The fact that marine ecosystem is extremely complex and processes within, such as trophic and non-trophic interaction, benthic-pelagic coupling and species interaction, are only partly understood leads to the conclusion that the system is inherently unpredictable.

However, various recent investigations in different parts of the world have shown that signals of climate variability can be detected at various trophic levels of the marine ecosystem, indicating that a major part of interannual and interdecadal biological variability can indeed be attributed to physical forcing (Cushing \&
Dickson 1976, Aebisher et al. 1990). Certain species show a linear response to climate variability in the northern hemisphere mainly during winter and spring. Correlations to climate variability have been identified for phytoplankton color index in the Northeast Atlantic (Reid et al. 1998, Edwards et al. 2001), for zooplankton in the Northeast Atlantic, the North Sea and the Baltic Sea (Taylor 1995, Fromentin \& Planque 1996, Dippner et al. 2000, 2001), for benthos in the North Sea, the Kattegat and the Gulf of Riga (Kröncke et al. 1998, Tunberg \& Nelson 1998, Dippner \& Ikauniece 2001), and various species of fish in different areas (Mann \& Drinkwater 1994, Binet 1997, Dippner 1997a, Mantua et al. 1997, Dippner \& Ottersen 2001).

In contrast, during summer and autumn, ecosystems are controlled by reproduction, succession or nonlinear predator-prey interaction (Dippner et al. 2001). A general overview is given by Drinkwater et al. (2003). Often a phase lag appears between climate forcing and the response in biological systems (Kröncke et al. 1998, Dippner et al. 2000, Dippner \& Ottersen 2001), which enables us to forecast climate-induced natural variability and changes in marine ecosystems. This is 

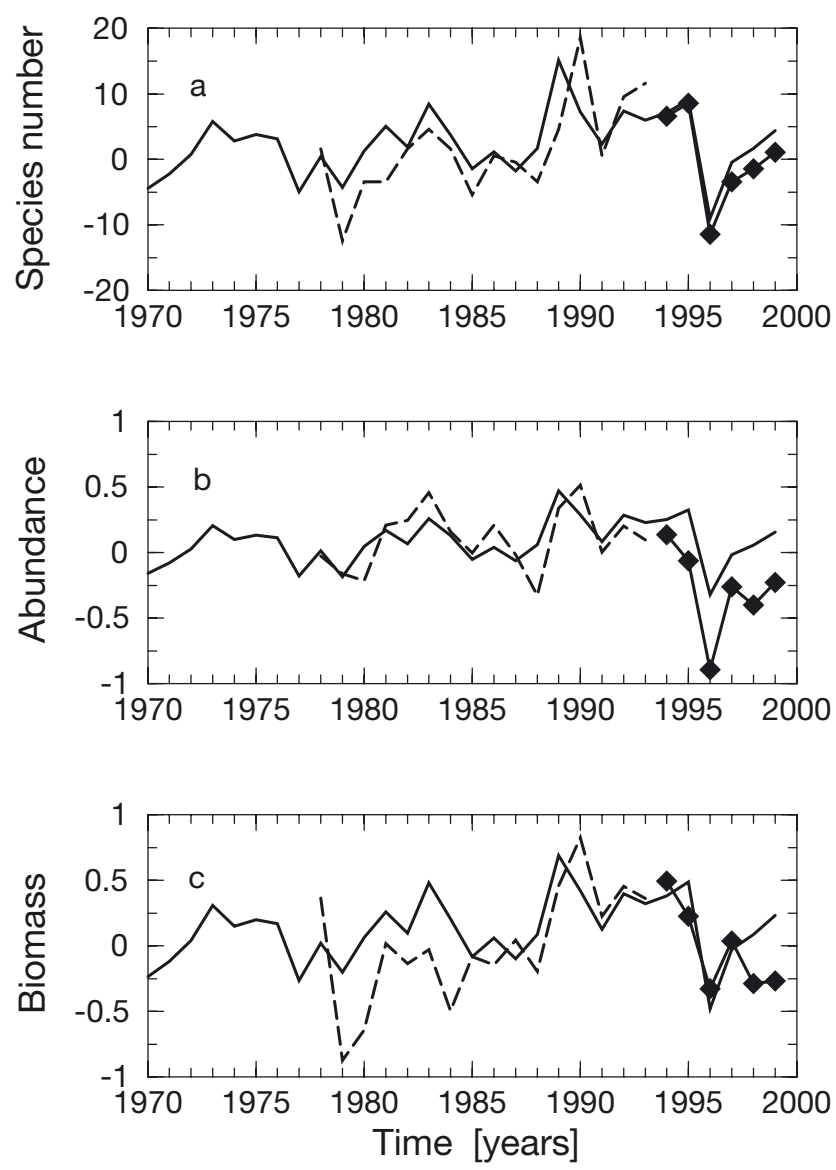

Fig. 1. Time series of anomalies of macrozoobenthos in the southern North Sea. Anomalies of (a) species per $\mathrm{m}^{2}$, (b) $\log$ abundance per $\mathrm{m}^{2}$ and (c) $\log$ biomass per $\mathrm{m}^{2}$ predicted from the NAO winter index (solid line). Observations in the fitting period 1978-1993: dashed line; observations in the forecast period 1994-1999: solid line with

demonstrated here on macrozoobenthos in the southern North Sea.

The benthic study area is situated north of the island of Norderney in the Wadden Sea (southern North Sea). Five monitoring stations were located at depths between 12 and $20 \mathrm{~m}$. Samples were taken monthly with a $0.2 \mathrm{~m}^{2}$ van Veen grab from 1978 to 1991, and in spring and late summer 1992. All samples were assessed taxonomically, and we found 196 macrofaunal taxa in 351 samples (81 Crustacea, 59 Polychaeta, 32 Mollusca, 9 Echinodermata and 15 others). Species number, abundance, and biomass (ash-free dry weight) were calculated as quarterly means per $0.2 \mathrm{~m}^{2}$ of the 5 stations (Kröncke et al. 2001). Abundance and biomass data were log-transformed, and anomalies were constructed by subtracting the long-term seasonal mean.

A multivariate regression model (von Storch et al. 1993) is applied to the data sets in the following way. Firstly, empirical orthogonal functions (EOFs) of the climate predictor and the biological predictands are calculated. Thus the major part of the variance from a multidimensional vector is concentrated in new dimensions, the leading eigenmodes. Secondly, a canonical correlation analysis (CCA) is performed between the leading eigenmodes of the climate predictors and the benthos time series. The CCA identifies pattern $\vec{C}$ and $\vec{B}$ and time series $\vec{C}$ and $\vec{b} \cdot \vec{C} \times C(t)$ represents a significant part of the variance of the climate predictor and $\vec{B} \times b(t)$ is the investigated benthos time series. $\vec{C}$ and $\vec{b}$ are optimally correlated to each other. Hence, thirdly, the benthos time series can be regressed from the predictor data as $\vec{B}_{\text {reg }}=\vec{B} \times C(t)$.

It has been shown in a previous paper (Kröncke et al. 1998) that the anomalies of these benthos time series in spring between 1978 and 1993 correlate highly to the North Atlantic Oscillation (NAO) winter index (Hurrell 1995); to the reanalyzed sea-level-pressure (SLP) field in winter (December to February average) at a resolution of $5 \times 5^{\circ}$ in the area 30 to $70^{\circ} \mathrm{N}, 70^{\circ} \mathrm{W}$ to $30^{\circ} \mathrm{E}$ (Trenberth \& Paolino 1980); and to the sea-surface temperature (SST) in the southern North Sea during wintertime (Dippner 1997b). All macrozoobenthos time series in spring are positively correlated to the SLP and SST fields in winter and to the NAO winter index. An anomaly in the NAO winter index of $1 \mathrm{hPa}$ corresponds to an anomalous log-abundance of 0.3 , to a species number anomaly of 3.8, and to an anomalous logbiomass of 0.6 . In all multivariate regressions a phase lag of 3 mo was identified between the climate predictors and the benthos time series, which enables us to perform predictions.

The CCA formally reduces to a plain regression if only 1 predictor and 1 predictand are used. In this case the vectors $\vec{C}$ and $\vec{B}$ reduce to scalar constants. To forecast the development of macrozoobenthos, we applied the same model to the data sets, considering the identified phase lag and using the NAO index as climate predictor. The model is fitted to the period 1978 to 1993, and a forecast of the development of the macrozoobenthos was made for the period 1994 to 1999 and compared to the observations (Fig. 1). Retransforming the regressed anomalies of log-biomass, logabundance and species numbers to biomass (BM), abundance (AB) and species number (SN) and considering that $\mathrm{NAO}(t)=C \times C(t)$, with $C$ as a scalar constant, we can give explicitly equations for the 3 benthic quantities as function of the NAO winter index only:

Biomass:

$$
B M(t)_{\text {spring }}=588.8 \times 10^{0.104 \times \mathrm{NAO}(t)}-1
$$

Abundance:

$$
A B(t)_{\text {spring }}=1950 \times 10^{0.079 \times \mathrm{NAO}(t)}-1
$$

Species number: $\quad S N(t)_{\text {spring }}=23.4+2.09 \times \mathrm{NAO}(t)$ As skill factors for the quality of the model, the correlation coefficient between the prediction and the macrozoobenthos observations and the Brier-based score $\beta$ 
Table 1. Correlation coefficients between observations and model results and Brier-based scores for the fitting period 1978-1993 and the prediction period 1994-1999

\begin{tabular}{|llc|}
\hline & Correlation & Brier-based score $\beta$ \\
\hline Fitting period & & \\
Species number & $0.67(\mathrm{p}<0.01)$ & 0.44 \\
Abundance & $0.73(\mathrm{p}<0.01)$ & 0.52 \\
Biomass & $0.56(\mathrm{p}<0.05)$ & 0.31 \\
Prediction period & & \\
Species number & $0.99(\mathrm{p}<0.001)$ & 0.87 \\
Abundance & $0.93(\mathrm{p}<0.01)$ & 0.17 \\
Biomass & $0.73(\mathrm{p}<0.1)$ & 0.39 \\
\hline
\end{tabular}

are used (Table 1). $\beta$ is defined as: $\beta=1-\sigma_{\mathrm{e}}^{2} / \sigma_{\mathrm{o}}^{2}$, where $\sigma_{\mathrm{e}}^{2}$ and $\sigma_{\mathrm{o}}^{2}$ are the variances of the error (i.e. observation minus model) and observation. $\beta=1$ means that model and observation are identical, $\beta=0$ that the error of the model has the same size as the variance of the observations (Livezey 1995). The high model skill indicates a linear response of the biological system in spring to climate variability during winter. Both the linear response and the phase lag make the climateinduced variability in the macrozoobenthos time series predictable.

Climatic factors play a dominant role in structuring macrozoobenthos communities in the North Sea, at least in winter and spring. The mediator between climate variability and benthic parameters is temperature, which is vertically homogeneous in the southern North Sea (Kröncke et al. 1998) due to the strong tidal mixing. Macrofauna communities are very sensitive to synergistic effects and are severely affected by temperature changes (Kröncke et al. 1998). Cold winters generally reduce species number, abundance and biomass of the macrozoobenthos in coastal regions of the North Sea (Kröncke et al. 1998). This was illustrated particularly well in the severe winter 1995/96 in the southern North Sea. In contrast, the extremely good correlation between NAO winter index and observations in the early 1990s can be explained by a high percentage of warm temperate macrofauna species in connection with mild winters (Kröncke et al. 1998).

The atmospheric winter circulation over the North Atlantic area and the NAO winter index are good predictors of the structure of the macrofauna communities in the following spring. Models which simulate climate-change scenarios are able to reproduce the past and predict the future NAO winter index (Cubasch et al. 1995, Hasselmann et al. 1995). Therefore, possible future developments of macrozoobenthos communities can be predicted for the next decades from those scenarios, and conclusions for long-term changes can drawn.
The knowledge of the response of macrozoobenthos in spring to climatic forcing during winter, and the predictability of the system some months in advance, will enable us in the future to differentiate between anthropogenic impact and natural climatic effects. The approach presented here, demonstrated on macrozoobenthos in the southern North Sea, is generally applicable to all areas in marine biology, from species level up to biodiversity, if a linear response and a phase lag can be identified. The forecasts are of vital interest for practical aspects of sustainable management of marine ecosystems or of integrated coastal zone management.

Acknowledgements. The authors are indebted to B. von Bodungen, S. Forster, H. Graßl, S. Güss, and M. McLachlan for helpful comments.

\section{LITERATURE CITED}

Aebischer NJ, Coulson JC, Colebrook JM (1990) Parallel long-term trends across four marine trophic levels and weather. Nature 347:753-755

Avaria S, Muñoz P (1989) Effects of the 1982-1983 El Niño on the marine phytoplankton off nothern Chile. J Geophys Res 92:14369-14382

Binet D (1997) Climate and fisheries in the Canary and Guinea currents 1964-1993: the role of trade winds and the southern oscillation. Oceanol Acta 20:177-190

Carrasco S, Santander H (1989) The El Niño event and its influence on the zooplankton off Peru. J Geophys Res 92: 14405-14410

Cubasch U, Hegerl G, Hellbach A, Höck H, Mikolajewicz U, Santer BD, Voss R (1995) A climate change simulation starting from 1935. Clim Dyn 11:71-84

Cushing DH, Dickson RR (1976) The biological response in the sea to climate change. Adv Mar Biol 14:2-122

Dippner JW (1997a) Recruitment success of different fish stocks in the North Sea in relation to climate variability. Dtsch Hydrogr Z 49:277-293

Dippner JW (1997b) A note on SST anomalies in the North Sea in relation to the North Atlantic Oscillation and the potential influence on the theoretical spawning time of fish. Dtsch Hydrogr Z 49:267-275

Dippner JW, Kornilovs G, Sidrevics L (2000) Long-term variability of mesozooplankton in the Central Baltic Sea. J Mar Syst 25:23-31

Dippner JW, Ikauniece A (2001). Long-term zoobenthos variability in the Gulf of Riga in relation to climate variability. J Mar Syst 30:155-164

Dippner JW, Ottersen G (2001) Cod and climate variability in the Barents Sea. Clim Res 17:73-82

Dippner JW, Hänninen J, Kuosa H, Vuorinen I (2001) The influence on zooplankton abundance in the Northern Baltic Archipelago Sea (SW Finland). ICES J Mar Sci 58: 569-578

Drinkwater KF, Belgrano A, Borja A, Conversi A and 5 others (2003) The response of marine ecosystems to climate variability associated with the North Atlantic Oscillation. In: Hurrell JW, Kushnir J, Ottersen G, Visbeck M (eds) The North Atlantic Oscillation-climatic significance and environmental impact. Geophys Monogr Ser 134:211-234 
Edwards M, Reid PC, Planque B (2001) Long-term and regional variability of phytoplankton biomass in the Northeast Atlantic (1960-1995). ICES J Mar Sci 58:39-49

Fromentin JM, Planque B (1996) Calanus and environment in the eastern North Atlantic. II. Influence of the North Atlantic Oscillation on C. finmarchicus and C. helgolandicus. Mar Ecol Prog Ser 134:111-118

Goldberg ED (1994) Coastal zone space. Prelude to conflict? UNESCO Publishing, Paris

Hasselmann K, Bengtsson L, Cubasch U, Hegerl GC, Rohde H, Roeckner E, von Storch H, Voss R, Waskewitz J (1995) Detection of anthropogenic climate change using a fingerprint method. In: Ditlevsen P (ed) Proceedings 'Modern Dynamical Meteorology', Symposium in Honour of Aksel Wiin-Nielsen, ECMWF Press, Reading, p 203-221

Hurrell JW (1995) Decadal trends in the North Atlantic Oscillation: regional temperatures and precipitation. Science 269:676-679

Kröncke I, Dippner JW, Heyen H, Zeiss B (1998) Long-term changes in macrofaunal communities off Norderney (East Frisia, Germany) in relation to climate variability. Mar Ecol Prog Ser 167:25-36

Kröncke I, Zeiss B, Rensing C (2001) Long-term variability in macrofauna species composition off the island of Norderney (East Frisia, Germany) in relation to changes in climate and environmental conditions. Senckenb Marit 31:65-82

Livezey RE (1995) The evaluation of forecast. In: von Storch $\mathrm{H}$, Navarra A (eds) Analysis of climate variability.

Editorial responsibility: Hans von Storch, Geesthacht, Germany
Springer-Verlag, Berlin, p 177-196

Mann KH, Drinkwater KF (1994) Environmental influences on fish and shellfish production in the Northwest Atlantic. Environ Rev 2:16-32

Mantua N, Hare SR, Zhang Y, Wallace JM, Francis RC (1997) A Pacific interdecadal climate oscillation with impacts on salmon production. Bull Am Meteorol Soc 78: 1069-1079

Reid PC, Edwards M, Hunt HG, Warner AJ (1998) Phytoplankton change in the North Atlantic. Nature 391:546

Russell FRS (1973) A summary of the observations on the occurrence of planktonic stages of fish off Plymouth 1924-1952. J Mar Biol Assoc UK 53:347-356

Taylor AH (1995) North-south shifts of the Gulf Stream and their climatic connection with the abundance of zooplankton in the UK and its surrounding seas. ICES J Mar Sci 52: $711-721$

Trenberth KE, Paolino DA Jr (1980) The northern hemisphere SLP-dataset: trends, errors and discontinuities. Mon Weather Rev 112:1999-2015

Tunberg BG, Nelson WG (1998) Do climatic oscillations influence cyclical patterns of soft bottom macrobenthic communities on the Swedish west coast? Mar Ecol Prog Ser 170:85-94

von Storch H, Zorita E, Cubasch U (1993) Downscaling of global climate change estimates to regional scales: an application to Iberian rainfall in wintertime. J Clim 6: 1161-1171

Submitted: December 10, 2002; Accepted: October 23, 2003 Proofs received from author(s): November 24, 2003 